\title{
Tulane
}

\author{
Tulane Economics Working Paper Series
}

\section{The Housing Crisis, Foreclosures, and Local Tax Revenues}

\author{
James Alm \\ J. Sebastian Leguizamon \\ Department of Economics Western Kentucky University \\ Tulane University j.sebastian.leguizamon@wku.edu \\ jalm@tulane.edu
}

Working Paper 1803

March 2018

\begin{abstract}
The housing crisis that began with the "Great Recession" led to a dramatic increase in home foreclosures, and these foreclosures likely had subsequent impacts on local government tax revenues. We investigate the impacts of foreclosures on local government tax revenues, using a reduced form estimation approach that relates changes in foreclosures to changes in local government tax revenues. Unlike most previous work, we examine the nationwide revenue impacts of foreclosures, using data across all local governments in the entire United States during the worst years of the Great Recession. We also examine the impacts of foreclosures on other local government sources of revenues beyond property tax revenues, including revenue sources that were likely affected by the impacts of foreclosures both on household wealth and on other forms of economic activity. Further, we focus in some specifications on the revenue effects for school districts only. Finally, we extend our analysis to the impacts of foreclosures on state governments revenues (and expenditures). Throughout, we use an instrumental variable approach to control for possible endogeneity of foreclosures and housing prices. Overall, we find evidence that the foreclosures created by the Great Recession had a direct, negative, but small effect on total tax revenues at the local level, although there is only weak evidence that this impact can be attributed to declines in local property taxes. However, we find that foreclosures had an indirect and negative impact on local governments via declines in state government funding. We suggest that foreclosures may have affected the real economy, thereby reducing the state government revenues dependent on real economic activity that were used to finance transfers to local governments.
\end{abstract}

Keywords: Foreclosures, property taxation, local government, intergovernmental transfers JEL codes: H2, H7, R3, R5 


\title{
The Housing Crisis, Foreclosures, ANd Local Tax ReVenues
}

\author{
James Alm and J. Sebastian Leguizamon*
}

\begin{abstract}
The housing crisis that began with the "Great Recession" led to a dramatic increase in home foreclosures, and these foreclosures likely had subsequent impacts on local government tax revenues. We investigate the impacts of foreclosures on local government tax revenues, using a reduced form estimation approach that relates changes in foreclosures to changes in local government tax revenues. Unlike most previous work, we examine the nationwide revenue impacts of foreclosures, using data across all local governments in the entire United States during the worst years of the Great Recession. We also examine the impacts of foreclosures on other local government sources of revenues beyond property tax revenues, including revenue sources that were likely affected by the impacts of foreclosures both on household wealth and on other forms of economic activity. Further, we focus in some specifications on the revenue effects for school districts only. Finally, we extend our analysis to the impacts of foreclosures on state governments revenues (and expenditures). Throughout, we use an instrumental variable approach to control for possible endogeneity of foreclosures and housing prices. Overall, we find evidence that the foreclosures created by the Great Recession had a direct, negative, but small effect on total tax revenues at the local level, although there is only weak evidence that this impact can be attributed to declines in local property taxes. However, we find that foreclosures had an indirect and negative impact on local governments via declines in state government funding. We suggest that foreclosures may have affected the real economy, thereby reducing the state government revenues dependent on real economic activity that were used to finance transfers to local governments.
\end{abstract}

Key Words: Foreclosures, property taxation, local government, intergovernmental transfers.

JEL Codes: H2, H7, R3, R5.

* Tulane University and Western Kentucky University. Please address all correspondence to James Alm, Department of Economics, Tulane University, 208 Tilton Hall, 6823 St. Charles Avenue, New Orleans, LA 70118 (phone +1 504862 8344; fax +1 504865 5869; email jalm@tulane.edu). We are grateful to the Editor and to two anonymous referees for many helpful comments and suggestions. 


\section{INTRODUCTION}

The housing market contraction that began with the so-called "Great Recession" of 20072009 has been blamed for much of the financial distress among local governments (The Nelson A. Rockefeller Institute of Government, 2010; Center on Budget and Policy Priorities, 2010; Mikesell and Mullins, 2010). Many observers believe that the financial crisis, fueled by subprime mortgage defaults, affected public sector institutions at all levels by putting much pressure on their budgets. While the channels are numerous and sometimes indirect, a common perception is that the foreclosures resulting from these defaults had a particularly large and negative impact on local government revenues, especially property tax revenues.

Reacting to such perceptions, a typical response from elected representatives was to introduce legislation to require a bank or other financial institution starting a foreclosure process to pay the affected jurisdiction the outstanding property taxes on the property. ${ }^{1}$ Indeed, when acquiring the title of a foreclosed home, the bank or financial institution does in fact assume all financial responsibilities of the home, including paying for upkeep, security, taxes, and insurance. However, these bank obligations do not appear to be binding while the property is still in the process of foreclosure; that is, the bank is only responsible once the bank regains possession of the property, a stage commonly known as "Real Estate Owned" (REO). This institutional feature, coupled with the likelihood that increasing numbers of foreclosures create both an excess supply of properties available for sale and so downward pressure on house prices, suggests that local governments could indeed experience a decrease in property tax revenue.

\footnotetext{
${ }^{1}$ For example, state Representative John M. Carnavale of Rhode Island (D-District 13, Providence) was quoted as saying: "[T]here is enormous pain and suffering in [Rhode Island] as a result of all of these foreclosures... but the suffering is not restricted to the individuals whose properties have been foreclosed upon, or tenants evicted from these homes. Cities and towns are losing vast sums of property tax revenue despite the fact that the property still exists and some entity - a bank or other mortgage lender - holds the property". Rep. Carnevale is still the elected representative of District 13.
} 
To date, much of the literature has focused on the negative effect of foreclosures on home prices and, through this channel, on the subsequent effect of home prices on local government property tax revenues. If local governments adjust tax assessment values quickly, then a decline in home prices can indeed have a negative impact on property tax revenues (Doerner and Ihlanfeldt, 2011; Alm, Buschman, and Sjoquist, 2011). Further, even if property tax revenues are not significantly affected due to slow adjustment in assessed values, total tax revenues may be adversely affected through other channels. As suggested theoretically by Lutz, Molloy, and Shan (2011) and demonstrated empirically by Mian, Suffi, and Trebbi (2015), the severity of the Great Recession not only affected house prices, but also other components of the real economy such as income, consumption, and, especially, wealth, with impacts on taxes imposed on these tax bases. Clearly, foreclosures can have both direct and indirect effects on local government revenues. Foreclosures can also have impacts on state government revenues.

However, establishing the link between foreclosures and these various economic variables - property tax revenues, other tax revenues, and broader economic outcomes - is complicated by the issue of causality. Foreclosures may reduce housing prices, which in turn reduce local tax revenues. Indeed, the presence of many realized foreclosures in a given area may affect nearby home values through two mechanisms: there may be a supply effect, in which foreclosures increase the supply of available homes and thus decrease home values; there may also be a disamenity effect created by the increase in foreclosed and neglected homes, in which homeowners become less likely to take care of a home that has entered a foreclosure process. Research to date shows that foreclosures have affected nearby home prices via both mechanisms. However, one mechanism has tended to dominate the other, depending on the type of neighborhood: low-priced, low-income, high-density, and high-crime neighborhoods tend to 
experience disamenity effects, while the supply effect appears to be stronger in most other neighborhoods (Immergluch and Geoff, 2006; Schuetz, Been, and Ellen, 2008; Harding, Rosenblatt, and Yao, 2009; Hartley, 2010; Campbell, Giglio, and Pathak, 2011; Towe and Lawley, 2013; Anenber and Kung, 2014; Fisher, Lambie-Hanson, and Willen, 2015, Alm et al. 2016).

However, a reverse causation between foreclosures and housing prices is also possible; that is, a weakening economy may lower housing prices, which then increases foreclosures, so that a decline in home values may be a causal factor in an increase in foreclosures. This reverse causation is something that many observers believe happened in the U.S. real estate crisis that began with Great Recession. As the market values of their homes fell, many homeowners found that their houses were worth less than the value of their mortgage loans; indeed, some homeowners owned multiple homes, which led them to foreclose strategically on multiple homes.

Determining the exact causal link is difficult and still unresolved (Lutz, 2008; Calomiris, Longhofer, and Miles, 2008; Lutz, Molloy, and Shan, 2011; Mian, Sufi, and Trebbi, 2015; Chatterjee and Eyigungor, 2015). Even so, it is certainly plausible that the combination of declining home values and foreclosures can cause a vicious cycle that can significantly affect local tax revenues. Estimating the revenue impact of foreclosures requires dealing with the potential endogeneity of foreclosures.

There are some studies that have tried to look at the relationship between foreclosures and property tax revenues. To date, most have examined specific cases. For example, Alm, Buschman, and Sjoquist (2011) focus on the state of Georgia, Vlaicu and Whalley (2011) provide results for California, Doerner and Ihlanfeldt (2011) focus on Florida, and Skidmore and 
Scorsone (2011) examine the specific circumstances of Detroit. In addition, Ihlanfeldt and Mayock (2015) examine the impact of foreclosures on Florida local governments, extending the usual analysis to both the revenue side and the expenditure side of government budgets. For the most part, these studies find that foreclosures are associated with lower government revenues, although the effect is often surprisingly small. Ihlanfeldt and Mayock (2015) also find significant impacts of foreclosures on expenditures, via such as channels as additional local government spending on fire, police, and social expenditures.

In this paper, we examine the link between foreclosures and local government revenues. We make several contributions. First, we focus on the broader and more comprehensive national experience, as opposed to a single state or jurisdiction. Second, we also examine the impact of foreclosures on other local government sources of revenues beyond property tax revenues, including revenue sources that were likely affected by the impact of foreclosures on household wealth and other forms of economic activity (e.g., income, consumption). Third, in some specifications we focus specifically on school district revenues, a sector that is particularly reliant on property taxes. Fourth, we also estimate the foreclosure impact on state government revenues and expenditures (including state government transfers to local governments), in an attempt to identify the channels through which foreclosures affected governments. In all of our empirical work, we deal explicitly with potential endogeneity of foreclosures, following the instrumental variable approach by Mian, Sufi, and Trebbi (2015) in their important recent work, in which we use state foreclosure laws as an instrument to identify the effect of foreclosures.

Overall, we find evidence that the foreclosures created by the Great Recession had a direct, negative, but small effect on total tax revenues at the local level, although there is only weak evidence that this negative effect can be attributed to declines in local property taxes. This 
result stems in large part from the great diversity in local government experience across the nation: even though local governments' property tax revenues may have been affected in some states, as often found in previous work, this effect may not be generalizable to the nation as a whole. This result also may follow from the lags in government adjustments in assessed/taxable values.

Interestingly, we also find that foreclosures had an indirect and negative impact on local governments via declines in state government funding. We suggest that foreclosures may have affected the real economy, as suggested by Mian, Suffi, and Trebbi (2015), thereby reducing state government revenues dependent on real economic activity. This indirect effect of foreclosures therefore limited the ability of state governments to transfer money to local governments via intergovernmental transfers. School districts were particularly affected by the decrease in state funding, although data limitations prevent us from examining the effect on other specific types of local governments.

\section{FRAMEWORK, DATA, AND ESTIMATION METHODS}

\subsection{Framework}

The Great Recession was an extraordinary shock that affected households in many different ways. The starting point was a significant decline in home values that led many homeowners to default on their mortgage payments and often to face foreclosure of their homes. As summarized by Mian, Suffi, and Trebbi (2015), evidence suggests the additional number of foreclosed homes put downward pressure on house prices, creating a "vicious spiral" in which foreclosures led to lower house prices, which in turn led to more foreclosures, and so on. 
A direct consequence of this massive wave of new foreclosures could be on property tax revenues because a decline in home values may decrease the property tax base, and thus property tax revenues. Of course, this impact depends upon how quickly governments adjust their assessed home values. Assessed values do not automatically change over time; that is, any decrease in the market value of housing does not necessarily and mechanically translate into a decrease in assessed values, and so into a decrease in revenues, in the absence of a formal and deliberate change in assessment. Lags in these re-assessments, combined both with caps on the amount by which assessed values can be changed in any given year and also with deliberate and possibly offsetting changes in millage rates, mean that changes in the market value of housing may not affect the tax base and thus property tax revenues in any immediate or obvious way, unlike other taxes that are much more closely linked to economic activity. ${ }^{2}$ In addition, there is significant variation in the reliance of local governments on property taxes, so that local governments will be differentially affected by any possible decline in property taxes.

There are also likely indirect effects of the Great Recession on local governments. Foreclosures had significant negative effects on real economic activity, decreasing household wealth and other forms of economic activity like income and consumption. The decline in economic activity likely led to declines in taxes, especially individual and corporate income taxes, retail sales taxes, and excise taxes (Lutz, Molloy, and Shan, 2011), taxes that are generally (if not always) of more importance to state governments than to local governments. ${ }^{3}$ In addition, most local governments typically receive significant amounts of funding from other sources, especially from state (and federal) government transfers, because most local jurisdictions do not generate sufficient funds to finance completely their local government expenditures from their

\footnotetext{
2 The assessment process is analyzed in detail by Diaz (1990), Quan and Quigley (1991), Wolverton and Gallimore (1999), and McAllister et al. (2003).

${ }^{3}$ Alm, Buschman, and Sjoquist $(2009,2011)$ found that these indirect effects on revenues can be substantial.
} 
own sources. Transfers also are used to equalize local government spending, especially for public education. If state government budgets were also affected by foreclosures, it is plausible that local governments may have been indirectly affected through decreases in state aid.

In sum, our framework suggests that the Great Recession may have had both a direct impact on local government revenues through its effect on foreclosures and an indirect impact on local government revenues through its effect on state government budgets.

\subsection{Data}

We focus our analysis on the changes in local government revenues between 2007 and 2009, using data from the Census of State and Local Government Finances. Although the Census provides disaggregated data for all types of local governments for some selected years, those data are not available for all the years we analyze. For example, we are able to find data broken down by counties, municipalities, townships, special districts, and school districts for the year 2007, but not for 2008 and beyond. For those later years, the Census aggregates all local governments into one category: "local governments". Due to this limitation much of our analysis focuses upon this broad definition of "local governments", which includes all local governments including counties, municipalities, townships, special districts, and school districts. We examine the changes in total tax revenues (Total Taxes) and its components (Property Taxes, Sales Taxes, Licenses) between 2007 and 2009, and including intergovernmental transfers from the state government (Revenues from State Government).

However, since property taxes play an especially important role in public school budgets, we also focus on public schools in some specifications. A separate section of the Census contains public elementary and secondary education finance data across U.S. school districts from 2007 through 2011. These data include identification and geographical variables such as the school 
system identification number (NCESID), the state core-based statistical area (CBSA), and the county where each school district is located. Additionally, those data include the total number of pupils enrolled in the system, the total revenues and expenditures of the school system, and a break-down of the revenue and expenditures sources. We use these data in our specifications that estimate the determinants of school district revenue growth between 2007 and 2009, examining the Total Revenues of the school districts as well as the revenue components (Revenues from State Government, Revenues from Own Sources, Revenues from Local Property Taxes) of the school districts.

Our crucial explanatory variable is foreclosures. We obtained data on foreclosures by private contract from RealtyTrac.com. These data are available at the zip code level for the period between 2006 and 2009, and are collected by RealtyTrac from documents submitted by lenders during the process of foreclosure. As discussed by Alm, Buschman, and Sjoquist (2014) and Mian, Sufi, and Trebbi (2015), RealtyTrac collects data on five types of filings, each of which depends on the state of the foreclosure process. A "notice of default" (NOD) and a "lis pendens" (LIS) are filings that occur prior to the auction of the foreclosed property. A "notice of trustee sale" (NTS) and a "notice of foreclosure sale" (NFS) are directly associated with the foreclosure auction. If the foreclosed property is purchased by the lender at auction, then the filing is classified as "real-estate owned" (REO). Since the pre-auction filing (either LIS and/or NOD) does not by itself lead to a sale or eviction, we measure total foreclosures per geographic unit as the sum of NTS and NFS. ${ }^{4}$ We do not have data on delinquencies or on the number of homeowners with a mortgage. Thus, we normalize foreclosures by the total number of housing units in a given jurisdiction.

\footnotetext{
${ }^{4}$ We follow Mian, Sufi, and Trebbi (2015) by excluding REOs since almost all of those follow a previous NTS or NFS. Including REOs may result in double counting.
} 
Figures 1 and 2 show the New Foreclosures, defined as the number of new foreclosures per housing unit by county and state during the peak of the foreclosure crisis (2008 and 2009). As expected, Florida, California, Arizona, Nevada, and Michigan are among the states with the highest foreclosure rates. Of some note is the significant variation in foreclosure rates, across states and within states, including much variation even within the high-foreclosure states.

Figures 3 and 4 show the decline in total tax revenues and in property tax revenues between 2007 and 2009 by state. These figures suggest that there may be a link between foreclosures and a decline in total tax revenues and, more specifically, in property tax revenues during the peak of the Great Recession (2008-2009). However, while there appears to be a link for some individual states, it is not clear that there is a link when we look at the entire U.S. Also, any links should be examined holding other variables constant, as we do in our empirical estimation.

We supplement these data with economic and demographic information for each geographic unit from the U.S. Census and the Bureau of Economic Analysis (BEA). Table 1 presents some descriptive information on these variables.

\subsection{Estimation Methods}

Our basic specification examines the effect of the number of new foreclosures per housing unit in state $s$ (New Foreclosures) on revenue growth of different revenue types for different levels of government in the state, controlling for potential endogeneity of $\mathrm{New}$ Foreclosures in a first stage estimation and using the predicted rate in a second stage estimation of revenue growth. We use a two-stage least squares (2SLS) estimation procedure because foreclosures may be endogenously determined. Mian, Sufi, and Trebbi (2015) suggest using state variation in foreclosure laws as an instrumental variable. Common law in the U.S. dictated that 
foreclosures should be resolved in court. However, some states have changed the law to allow for non-judicial foreclosures. In states with judicial requirements, foreclosures must go through a court procedure in which the time to clear the process is typically longer. Since foreclosing on a property can be long and costly, banks are understandably interested in a swift process. In contrast, in states without judicial requirements the parties involved in the foreclosure process can avoid court delays, increasing the ability to foreclose faster and thereby also increasing the number of overall foreclosed properties. State variation in foreclosure laws may therefore serve as an appropriate instrument for dealing with potential endogeneity of foreclosures.

More formally, we estimate a two-stage system:

$$
\begin{aligned}
& \text { New Foreclosures } \text { Fo }_{s}=\alpha+\beta_{1} \text { Judicial Requirement }{ }_{s}+\sum \beta_{i} X_{i s}+\eta_{s} \\
& \operatorname{Ln}\left(\text { Revenues } 2009_{s}\right)-\operatorname{Ln}\left(\text { Revenues } 2007_{s}\right) \\
& =\gamma+\theta \text { New } \widehat{\text { Foreclosures }}+\sum \psi_{i} X_{i s}+\varepsilon_{s}
\end{aligned}
$$

In the first stage equation (1), we regress the number of new foreclosures per housing unit in 2008 and 2009 in state $s$ on a dummy variable (Judicial Requirement) equal to 1 if state $s$ requires a judicial procedure to foreclose homes and 0 otherwise, along with several statespecific control variables $X_{i s}$, where $i$ denotes the control variable. In the second stage equation (2), we use the predicted value of foreclosure rates from the first stage to explain the variation in revenue growth of state $s$ between 2007 and 2009, along with the state-specific control variables. We focus on the change in revenues between 2007 and 2009 since this period covers the peak of the foreclosure crisis. By 2010 the differences in new foreclosure notices between states with and without judicial laws had almost disappeared, which suggests that foreclosures acted mainly as a temporary shock whose effects were felt in 2007-2009 and were largely dissapated by 2010. 
Note that our measure New Foreclosures is a measure of new foreclosures per total number of housing units (a flow variable), rather than the difference in total foreclosures (a stock variable). This is convenient since the instrument (Judicial Requirement) can explain spatial differences in new foreclosures and still be able to explain changes in revenue.

Figure 5 shows a map of states with and without judicial laws. Mian, Sufi, and Trebbi (2015) show that new foreclosure filings (i.e., New Foreclosures) are indeed correlated with the existence of non-judicial laws in the state. One may argue that judicial and non-judicial states are systematically different in other relevant factors, some of which could influence foreclosure rates, making this correlation spurious. Mian, Sufi, and Trebbi (2015) perform numerous tests that provide support for the validity of judicial laws as an instrument. ${ }^{5}$ Accordingly, we follow Mian, Sufi, and Trebbi (2015) in using the presence of judicial laws as an instrument. It should be noted that, although we can dissagregate the foreclosure rate and school district finances to the county level, the source of identification that we employ comes from the variation in state laws. As such, we aggregate foreclosures, local government finances, and school district finances to the state level, and we conduct our various empirical analyses at the state level.

We look at a number of different revenue categories, including property tax revenues but also additional classifications. As mentioned above, although new foreclosures seem more likely to affect property tax revenue directly via the property tax base, it is also possible that other sources of revenue may have been affected indirectly. In order to control for state characteristics that may have influenced revenues, we include a set of state-specific controls in $X_{i s}$ such as income per capita in 2005 , the unemployment rate in 2000 , house price growth from 2000 to

\footnotetext{
${ }^{5}$ See Mian, Sufi, and Trebbi (2015) for a complete description of those tests. They use state discontinuity tests, among others, to show that states with different laws are statistically similar to each other along many variables, including those that can affect foreclosure rates directly, such as income and the number of delinquencies. They find no difference along demographic characteristics, and no real pattern in the way that some states became judicial states.
} 
2005, the percent of males, the percent white, the percent Hispanic, the percent of owner occupied homes, the percent of the population with a bachelor's degree or above, the percent urban, the percent of families with income less than $\$ 25,000$ in the year 2000, the percent of families classified as poor, the average household size, and the percent of all revenue in 2006 that came from the federal governmnet and the state government. All control variables are measured at the state level, and, unless otherwise indicated, they are measured in year 2000.

An important concern is the geographic concentration of states with judicial foreclosure laws. As seen in Figure 5, the spatial distribution does not appear random. Although there are some Western states with judicial laws, most of them are concentrated in the Northeast. As noted by Mian, Sufi, and Trebbi (2015), it is possible that regional economic shocks, which correlate with foreclosure laws, may drive any results. ${ }^{6}$

In order to alleviate this concern, we follow Mian, Sufi, and Trebbi (2015) and perform a state-border analysis for the same 2007-2009 period of analysis. We form pairs of states that border each other (a total of 109 state-pairs), and for each pair we compute the difference $(\Delta)$ between the two states' foreclosure rates ( $\Delta$ New Foreclosures $\left.{ }_{p}\right)$, revenue growth ( $\Delta$ Revenue Growt $h_{p}$ ), and foreclosure laws ( $\Delta$ Foreclosure Law $\left._{p}\right)$, where $p$ denotes a state pair. We then instrument the difference in the state-pair's foreclosure rates with the difference in the state-pairs' foreclosure laws, so that the variation in foreclosure rates is driven by differences across states that border each other, and not by regional effects. The 2SLS regression is given by:

$$
\begin{aligned}
& \Delta \text { New Foreclosures } p=\alpha+\beta_{1} \Delta \text { Foreclosure Law } p+\epsilon \\
& \Delta \text { Revenue } \text { Growth }_{p}=\delta+\gamma_{1} \Delta \text { New Foreclosures } s_{p}+u
\end{aligned}
$$

Again, $p$ denotes a state pair, and $\Delta$ denotes the difference.

\footnotetext{
${ }^{6}$ We thank an anonymous referee for emphasizing this possibility.
} 


\section{RESULTS}

Table 2 shows the estimation results for the impact of new foreclosures on five different local government revenue categories. As noted above, we aggregate revenues for all local governments in the state, and we examine the effect of new foreclosures per housing unit in 2008 and 2009 on revenue growth during the peak of the Great Recession, where various measures of the growth in local government revenues (Total Taxes, Property Taxes, Sales Taxes, Licenses, Revenues from State Government) are used as dependent variables. Table 2 also includes the estimates for the first stage regression, which show that judicial laws are negatively and statistically significantly correlated with new foreclosures.

The wave of new foreclosures had a negative and statistically significant impact on local government revenue growth of Total Taxes. The estimated coefficient on the predicted New Foreclosures suggests that a one-standard-deviation increase in the number of new foreclosures per household in 2008 and 2009 generated a 5.97 percent drop in the growth rate of Total Taxes. The individual components of local government revenues (Property Taxes, Sales Taxes, Licenses) were also negatively affected by foreclosures, but these impacts were not statistically signifiant. For example, local governments in states with higher numbers of new foreclosures experienced higher declines in property tax revenue, with a coefficient whose p-value is barely above the 10 percent significance level, at 10.6 percent. The coefficients on sales tax revenue growth and licenses revenue growth are also negative but are not statistically significant. ${ }^{7}$

\footnotetext{
${ }^{7}$ Although the first stage F-statistic is not particularly large, the Kleibergen-Paap Wald rk Fstatistic (6.13) is large enough to reject the null that the size of the Wald test is unacceptably larger than 5 percent at a tolerable rate of 25 percent, according to the critical values in Stock and Yogo (2005). A conditional likelihood ratio test, like the one suggested by Moreira (2003), indicates that our estimate is robust under the weak instrument. For the case of Total Taxes and Revenues from State Government, our estimate for New Foreclosures is statistically different from zero at least at the 90 percent confidence level.
} 
Since most local governments receive large portions of funding aid from their state governments, we also investigate in Table 2 whether the foreclosure crisis negatively affected this source of revenue (Revenues from State Government). We find some evidence that states where the foreclosure crisis hit harder also experienced larger decreases in aid from state to local governments. Note that one should be careful when interpreting this result. While the purpose of the instrument is to determine direct causality between new foreclosures and local government revenues, it is unlikely that this direct relationship exists when it comes to Revenues from State Government. Property taxes are not a significant part of state budgets in the U.S., and indeed a few state governments do not collect any property tax revenues. Consequently, we expect only an indirect, even if suggestive, relationship between New Foreclosures and Revenues from State Government. A more likely link is that the foreclosure crisis affected some state governments through income, sales, and other taxes, so that they had to adjust their budgets opting to reduce their aid to local governments. We explore this hypothesis further below.

In Table 3 we present similar estimation results for school districts, a local government sector that in many cases relies heavily on property taxes. ${ }^{8}$ Although we are unable to disaggregate results into specific types of local governments from the Census data, the Census provides separate financial data on each of the approximately 13,500 school districts. We are able to perform a similar analysis on school district revenues and its components, or Total Revenues, Revenues from State Government, Revenues from Own Sources, and Revenues from Local Property Taxes. ${ }^{9}$ We now find little statistical evidence of an impact of foreclosures on

\footnotetext{
${ }^{8}$ Note that most school districts across the U.S. receive state government transfers, and these transfers exhibit significant variation across school districts, both within and between states. We account for this variation by including an additional variable, Percent of Revenue from the State Government (for year 2006) in the estimation.

${ }^{9}$ Note that Total Revenues include Revenues from State Government and Revenues from Own Sources. Also, Revenues from Local Property Taxes are a part of Revenues from Own Sources, which includes all taxes, parent government contributions, revenues from cities and counties, revenues from other school systems, charges, and other local revenues.
} 
property tax revenue growth, total revenue growth, or growth in revenue from local sources.

However, as with local governments, we find slower growth in revenue from state governments in school districts located in states where the foreclosure shock was more severe. ${ }^{10}$

Tables 4 and 5 contain the results using the bordering state-pair analysis, which attempts to alleviate concerns that our results are driven by regional shocks. In general, we find that our bordering results are robust and mostly consistent with those in Tables 2 and 3. For all local governments (Table 4), New Foreclosures are again negatively and signicantly associated with declines in the growth of Total Taxes and the growth of Revenues from State Government. For school districts (Table 5), foreclosures again lead to a decline in intergovernmental transfers from the state government; however, New Foreclosures now also generate a decline the growth of Total Revenues, a result that is statistically significant at the 10 percent significance level, and the foreclosurse impact on the growth of local property taxes is close to statistical significance, with a p-value of 0.113 .

We perform a similar analysis using state government finances in order to examine the potential effects that foreclosures may have had on state government budgets. Tables 6 and 7 present the results. We find no evidence of an impact of new foreclosures on any of the components of state revenue growth. However, in unreported results, we find suggestive evidence that there seems to be a state government adjustment in state transfers to school

\footnotetext{
${ }^{10}$ Note that the school finance equalization in the states may contribute to these results. In states with full school finance equalization (e.g., California), school districts may have stronger incentives to adjust the property tax base downward because any lost revenues can be expected to be compensated via state-level school finance equalization contributions. In contrast, in states with little equalization (e.g., Massachusetts) local school districts may have fewer incentives to adjust their tax base downwards. We are grateful to an anonymous referee for this observation.
} 
districts (and to some other components of state government expenditures), as a result of new foreclosures. $^{11}$

Taken together, the findings suggest that, although there is some weak evidence that property tax revenue growth may have been directly affected by the rate of new foreclosures during the peak of the Great Recession, there seems to be an indirect impact coming through a decline in state funding to local school districts. An interesting finding is that the wave of new foreclosures did not seem to affect state sales and income tax revenue growth directly. This suggests that there might be other unexplored avenues that may have prompted state governments in high foreclosure states to adjust their funding to school districts. ${ }^{12}$

These results confirm what is suggested by Figures 1 to 4 . They highlight the lack of strong support for the idea that the wave of new foreclosures during the Great Recession affected local revenues directly, at least for the "average" local government. The finding that local revenues were affected indirectly through state funding is partially supported by Figures 6 through 8; when compared to Figure 2 (i.e., new foreclosures per state), we see that there is a correlation between new foreclosures and declines in local revenues coming from state governments, particularly for school districts.

\section{SUMMARY AND CONCLUSIONS}

\footnotetext{
${ }^{11}$ Unlike the case of local governments, state government finance data provide disaggregated information on intergovernmental expenditures to school districts and to other local governments. Also note that education expenditures do not include transfers to school districts, but do include expenditures on higher education. ${ }^{12}$ Some further, if mainly suggestive, evidence for the indirect channels through which foreclosures affected local revenues can be seen in some simple correlations between foreclosures and various state-level economic variables. To examine these indirect effects, we calculated the simple correlation coefficient between new foreclosures and several different state economic variables: the growth from 2007 to 2009 in per capita state personal income, in per capita net earnings, and in per capita personal expenditures. The correlations between new foreclosures per housing unit and these three variables are, respectively, $-0.6934(p$-value $=0.0000)$ for income, $-0.7342(p$-value $=0.0000)$ for earnings, and -0.6984 ( $\mathrm{p}$-value $=0.0000$ ) for expenditures. These negative correlations are consistent with the notion that foreclosures worked to decrease local revenues mainly through their indirect effects on the economically sensitive tax bases of state governments.
} 
How did new foreclosures generated by the Great Recession affect local government revenues? The results in this paper suggest that the common and widely held notion that local governments were severely hit by the extraordinary increase in foreclosures stemming from the financial crisis is only partially correct. We find some limited evidence that the growth rates of total revenues of local governments in general and school districts in particular were in fact negatively affected on average by foreclosures. Indeed, our results suggest that the impact of foreclosures on the growth of property tax revenues was negative but statistically insignificant. However, we also find some suggestive evidence that the channel for the impacts both on local governments and on school districts was less through the direct impact of new foreclosures on local tax revenues but more through the indirect impact of the broader financial crisis via state government transfers. In particular, the decline in economic activity generated by the financial crisis (of which the increase in foreclosures was often seen as the most obvious impact) significantly and negatively affected the ability of state governments to maintain their transfers to local school districts. It seems that it was largely through this indirect channel (e.g., state government transfers) that the financial crisis affected school districts.

These results are consistent with the existence of enormous variation in the experiences of local governments. As demonstrated convincingly by the work of others in specific state and local contexts (Alm, Buschman, and Sjoquist, 2011; Vlaicu and Whalley, 2011; Doerner and Ihlanfeldt; Skidmore and Scorsone, 2011), there were certainly instances of severe fiscal stress at the local government level, driven largely by foreclosures. However, there were also many instances were local governments were largely unscathed by the Great Recession. It may well be 
that our failure to find much of a nationwide impact of foreclosures on local tax revenues is due largely to the commingling of local governments with these widely varying experiences. ${ }^{13}$

This conclusion does not necessarily mean that another real estate crisis, fueled by accelerated rates of foreclosures, would not be detrimental to local government budgets. Indeed, to the extent that state goverments are affected, and through them local entities like local governments and school districts, one should be concerned with the potential for another similar crisis. This is of particular concern given the recent 2015-2016 surge in home prices. This surge could be a signal of an overheated housing market, and the bursting of this new housing bubble might well lead to similar effects on local government budgets as in the Great Recession.

\section{REFERENCES}

Alm, James (2017). Is economics useful for public policy? Southern Economic Journal, forthcoming.

Alm, James, Buschman, Robert D., \& Sjoquist, David L. (2009). Economic conditions and state and local education revenue. Public Budgeting \& Finance, 29 (3), 28-51.

Alm, James, Buschman, Robert D., \& Sjoquist, David L. (2011). Rethinking local government reliance on the property tax. Regional Science and Urban Economics, 41 (4), 320-331.

Alm, James, Buschman, Robert D., \& Sjoquist, David L. (2014). Foreclosures and local government revenues from the property tax: The case of Georgia school districts. Regional Science and Urban Economics, 46, 1-11.

Alm, James, Hawley, Zackary, Lee, Jin Man, \& Miller, Joshua J. (2016). Property tax delinquency and its spillover effects on nearby properties. Regional Science and Urban Economics, 58, 71-77.

Alm, James, Hodge, Timothy R., Sands, Gary, \& Skidmore, Mark. (2015). Property tax delinquency-Social contract in crisis: The case of Detroit. Public Finance and Management, 14 (3), 290-305.

Anderson, Nathan B. (2011). No relief: Tax prices and property tax burdens.Regional Science and Urban Economics, 41 (6), 537-549.

\footnotetext{
${ }^{13}$ In a similar way,

\{"Attachments":[\{"_type":"ItemIdAttachment:\#Exchange","ItemId":\{"ChangeKey":"CQAAABYAAACqnCPR5L 11Qr4BbgWOGbRSAAO8tjsy","Id":"AAMkADdkZWJhYWQ3LTUyYjAtNDRmZS1iOWI0LTU1MDQwZWYw MWIxNgBGAAAAAACZRri6AJUJSImgDm5C/ilUBwDMYu3c1w0URqgV6x2HCGVuAAAAQnW3AACqnCPR 5L11Qr4BbgWOGbRSAAO6VcgNAAA=" \},"Name":"Jim Berry","IsInline":false,"Size":35786\}]\} sAlm (2017) argues that most attempts to identify "best practices" that apply in all settings will lead to poor policy advice in most specific settings, given the many ways in which individuals, firms, markets, countries, and times differ.
} 
Anderson, Nathan B., \& Miller, Joshua J. (2015). Property tax delinquency: Fees and foreclosure in the United States. State Tax Notes, 22 June 2015, 939-944.

Anenber, Elliot, \& Kung, Edward (2014). Estimates of the size and source of price declines due to nearby foreclosures. The American Economic Review, 104 (8), 2527-2551.

Calomiris, Charles W., Longhofer, Stanley D., \& Miles, William (2008). The foreclosure-house price nexus: lessons from the 2007-2008 housing turmoil. NBER Working Paper No. w14294. Cambridge, MA: National Bureau of Economic Research.

Campbell, John Y., Giglio, Stefano, \& Pathak, Parag (2011). Forced sales and house prices. The American Economic Review, 101 (5), 2108-2131.

Center on Budget and Policy Priorities (2010). An update on state budget cuts (19 April 2010), available online at: http://www.cbpp.org/cms/index.cfm?fa=view\&id=1214.

Chatterjee, Satyajit, \& Eyigungor, Burcu (2015). A quantitative analysis of the US housing and mortgage markets and the foreclosure crisis. Review of Economic Dynamics, 18 (2), 165 184.

Chernick, Howard, Langley, Adam, \& Reschovsky, Andrew (2011). Revenue diversification and the financing of American central cities. Public Finance and Management, 11 (2), 138.

Doerner, William M., \& Ihlanfeldt, Keith R. (2011). House prices and local government revenues. Regional Science and Urban Economics, 41 (4), 332-342.

Diaz, III, Julian (1990). How appraisers do their work: A test of the appraisal process and the development of a descriptive model. The Journal of Real Estate Research, 5 (1), 1-15.

Fisher, Lynn M., Lambie-Hanson, Lauren, \& Willen, Paul (2015). The role of proximity in foreclosure externalities: Evidence from condominiums. American Economic Journal: Economic Policy, 7 (1), 119-140.

Harding, John P., Rosenblatt, Eric, \& Yao, Vincent W. (2009). The contagion effect of foreclosed properties. Journal of Urban Economics, 66 (3), 164-178.

Hartley, Daniel (2010). The effect of foreclosures on nearby housing prices: Supply or disamenity? Federal Reserve Bank of Cleveland Working Paper 10-11. Cleveland, OH.

Ihlanfeldt, Keith, \& Mayock, Tom (2015). Foreclosures and local government budgets. Regional Science and Urban Economics 53, 135-147.

Immergluck, Dan, \& Smith, Geoff (2006). The external costs of foreclosure: The impact of single-family mortgage foreclosures on property values. Housing Policy Debate 17 (1), 57-79.

Immergluck, Daniel (2010). Neighborhoods in the wake of the debacle: Intrametropolitan patterns of foreclosed properties. Urban Affairs Review,46 (1), 3-36.

Immergluck, Daniel (2011). The local wreckage of global capital: The subprime crisis, federal policy, and high-foreclosure neighborhoods in the U.S. International Journal of Urban and Regional Research, 35 (1), 130-146.

Lutz, Byron (2008). The connection between house price appreciation and property tax revenues. National Tax Journal, 61 (3), 555-572.

Lutz, Bryon, Molloy, Raven, \& Shan, Hui (2011). The housing crisis and state and local government tax revenue: Five channels. Regional Science and Urban Economics, 41 (4), 306-319.

McAllister, Pat, Baum, Andrew, Crosby, Neil, Gallimore, Paul, \& Gray, Adelaide (2003). Appraiser behavior and appraisal smoothing: Some qualitative and quantitative evidence". Journal of Property Research, 20 (3), 261-280. 
Mian, Atif, Sufi, Amir, \& Trebbi, Francesco (2015). Foreclosures, house prices, and the real economy. The Journal of Finance, 70 (6), 2587-2634.

Mikesell, John L., \& Mullins, Daniel R. (2010). State and local revenue yield and stability in the Great Recession. State Tax Notes, 55(25 January 2010), 267-274.

Moreira, M. (2003): "A Conditional Likelihood Ratio Test for Structural Models," Econometrica, 71 (4), 1027-1048

Quan, Daniel. C., \& Quigley, John M. (1991). Price formation and the appraisal function in real estate markets. The Journal of Real Estate Finance and Economics, 4 (2), 127-146.

The Nelson A. Rockefeller Institute of Government (2010). Revenue declines less severe, but states' fiscal crisis is far from over (April 2010, No. 79).

Schuetz, Jenny, Been, Vicki, \& Ellen, Ingrid Gould (2008). Neighborhood effects of concentrated mortgage foreclosures. Journal of Housing Economics, 17 (48), 306-319.

Skidmore, Mark, \& Scorsone, Eric (2011). Causes and consequences of fiscal stress in Michigan municipal governments. Regional Science and Urban Economics, 41 (4), 360-371.

Towe, Charles, \& Lawley, Chad (2013). The contagion effect of neighboring foreclosures. American Economic Journal: Economic Policy, 5 (2), 313-335.

Vlaicu, Razvan, \& Whalley, Alexander (2011). Do housing bubbles generate fiscal bubbles? Evidence from California cities. Public Choice, 149 (1), 89-108.

Wolverton, Marvin L., \& Gallimore, Paul (1999). Client feedback and the role of the appraiser. Journal of Real Estate Research, 18 (3), 415-431. 
Figure 1. New Foreclosures across U.S. Counties, 2008 and 2009

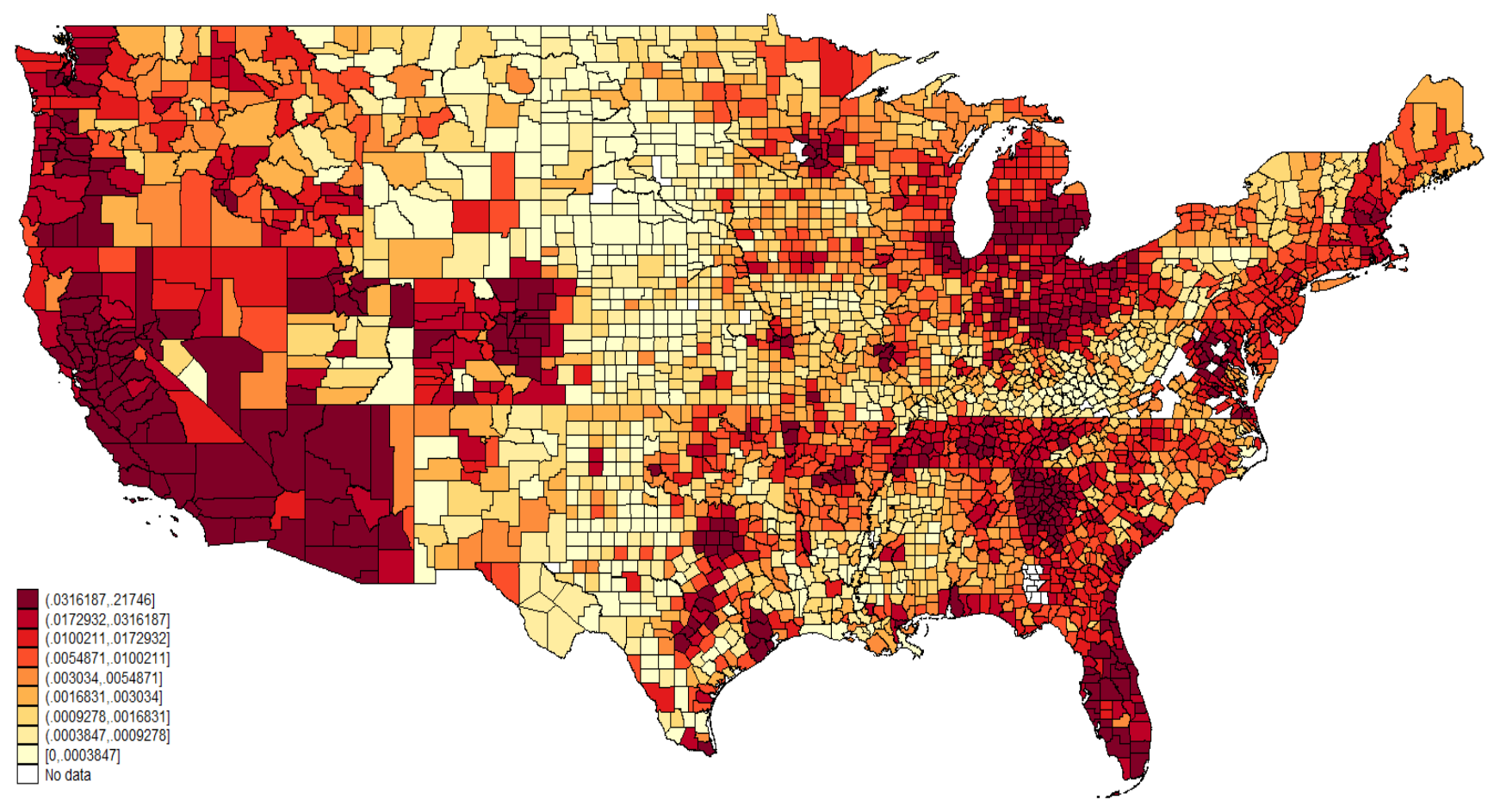

Note: Foreclosure data at the zipcode level come from RealtyTrac.com, and are aggregated at the county level. The darkest shades represent the highest foreclosure rates. 
Figure 2. New Foreclosures across U.S. States, 2008 and 2009

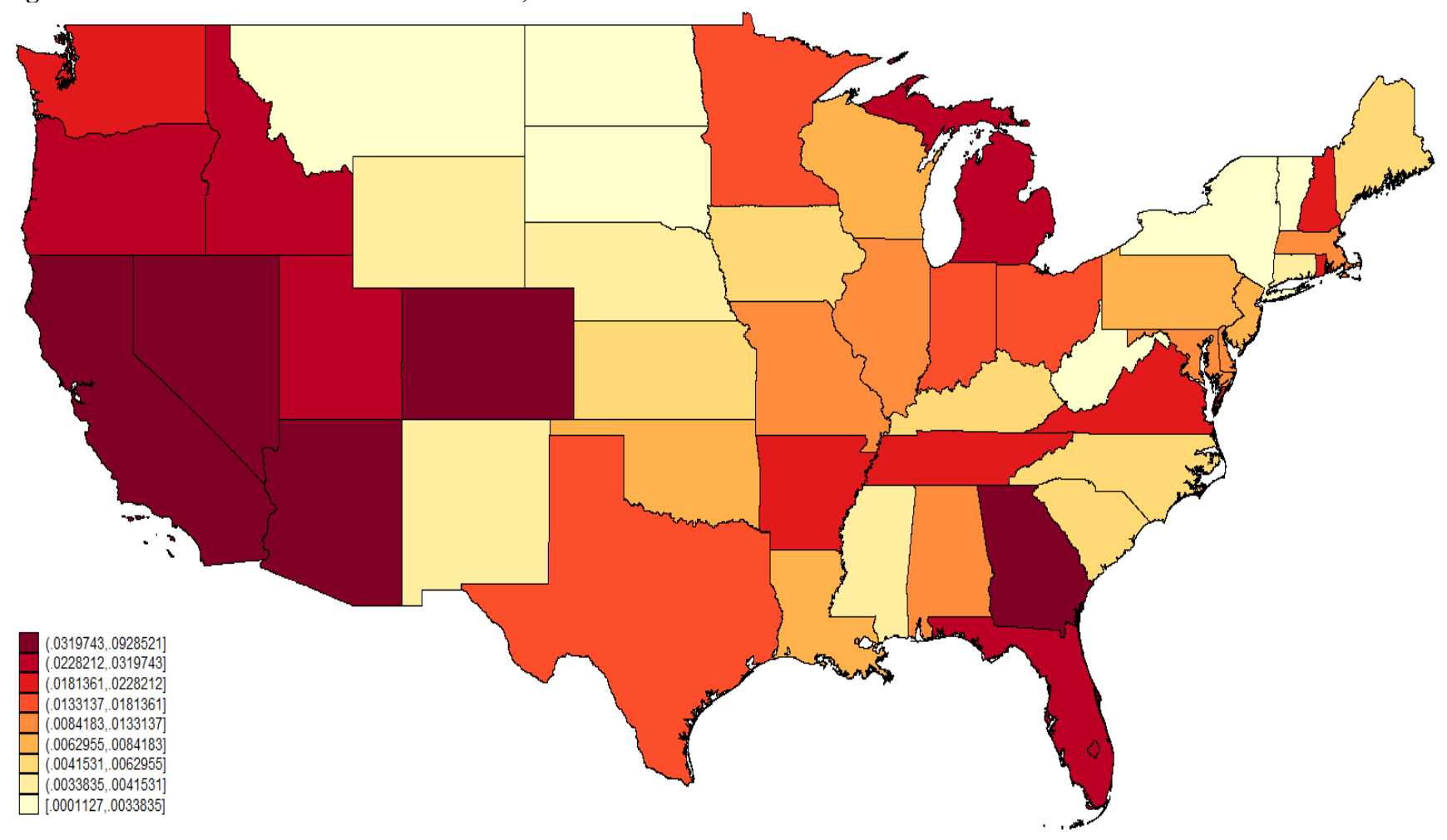

Note: Foreclosure data at the zipcode level come from RealtyTrac.com, and are aggregated at the state level. The darkest shades represent the highest foreclosure rates. 
Figure 3. Percent Decline in Local Government Per Capita Total Tax Revenues from 2007 to 2009

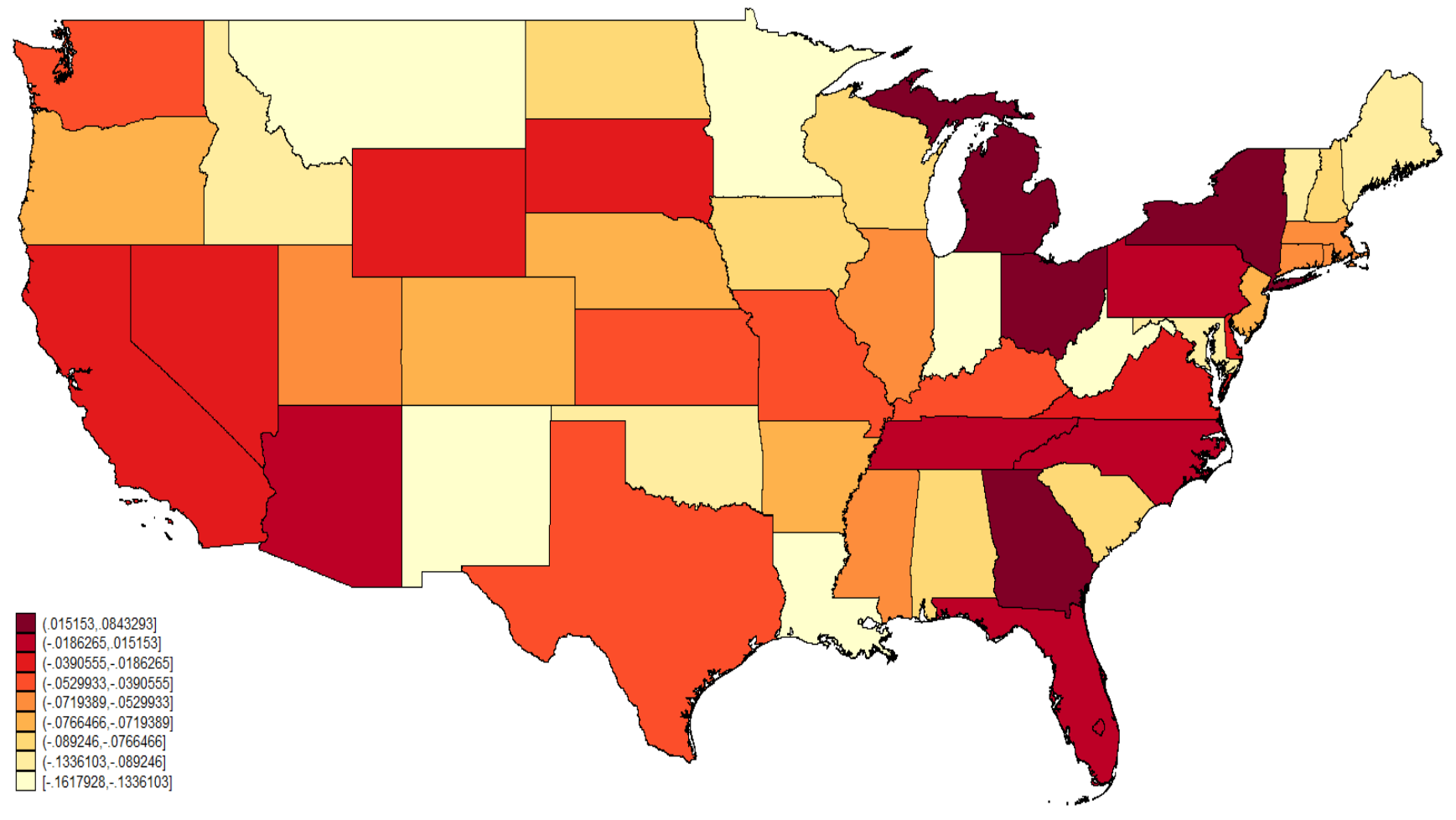

Note: Local government revenues are aggregated at the state level. The darkest shades represent the highest percent decline in revenues while the lighter shades represent lower declines or even negative declines (i.e., revenue growth). 
Figure 4. Percent Decline in Local Government Per Capita Property Tax Revenues from 2007 to 2009

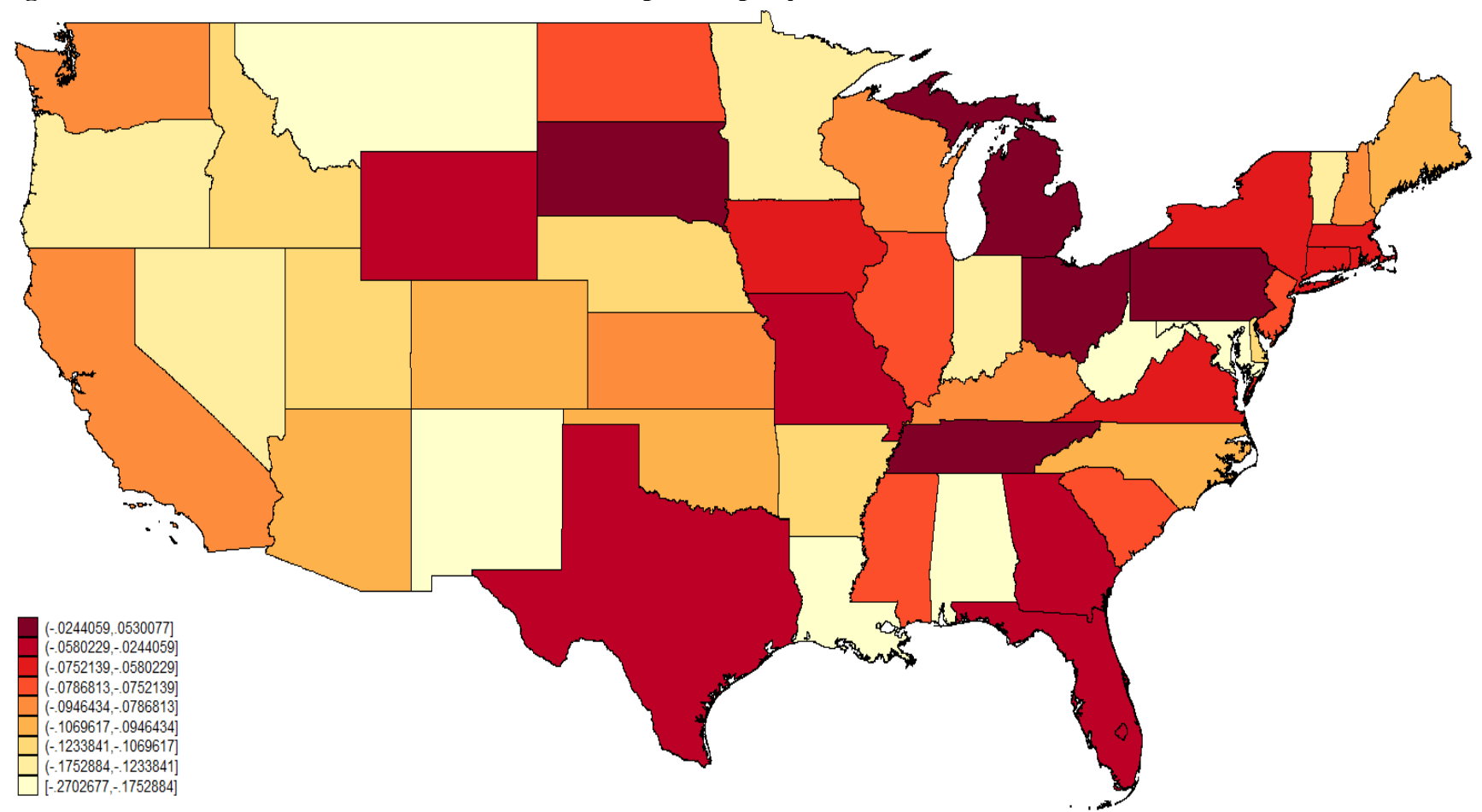

Note: Local government revenues are aggregated at the state level. The darkest shades represent the highest percent decline in revenues while the lighter shades represent lower declines or even negative declines (i.e., revenue growth) 
Figure 5. States with Judicial Foreclosure Requirements

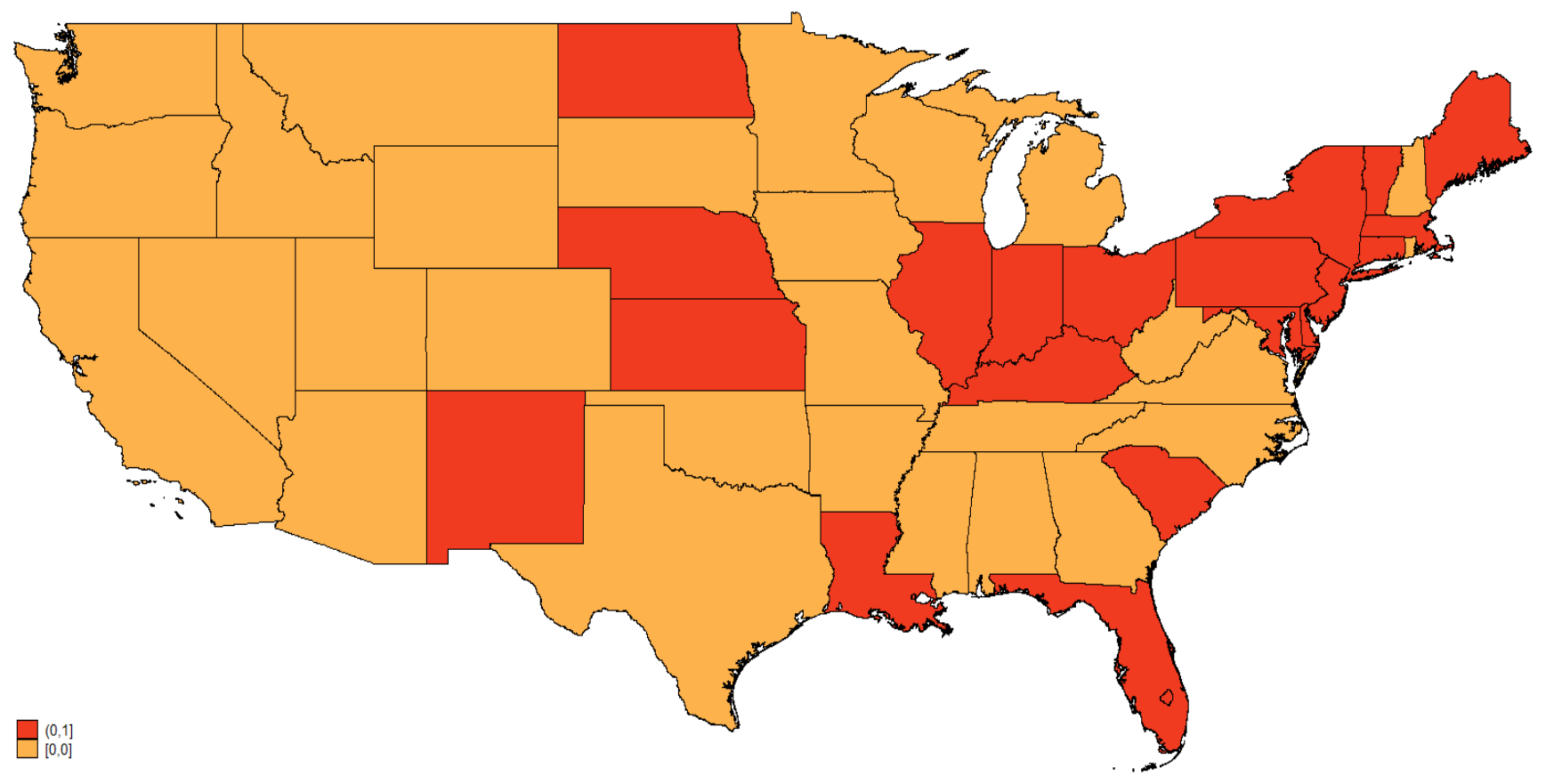

Note: Dark shades require judicial foreclosure. Data are obtained from RealtyTrac.com 
Figure 6. Percent Decline in Local Government Intergovernmental Revenues from the State (2007 to 2009)

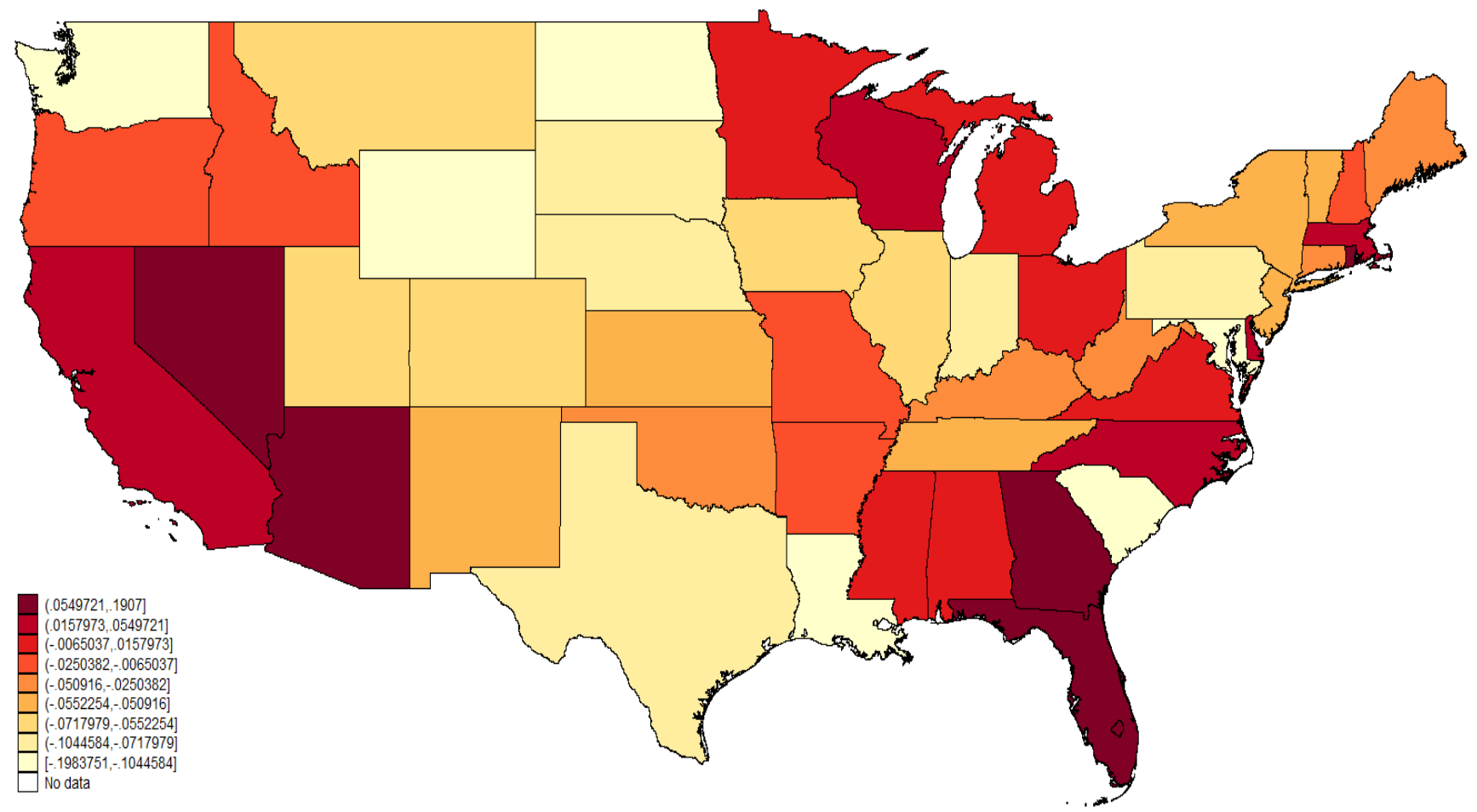

Note: Local government revenues are aggregated at the state level. The darkest shades represent the highest percent decline in revenues while the lighter shades represent lower declines or even negative declines (i.e., revenue growth) 
Figure 7. Percent Decline in School District Intergovernmental Revenues from the State (2007 to 2009)

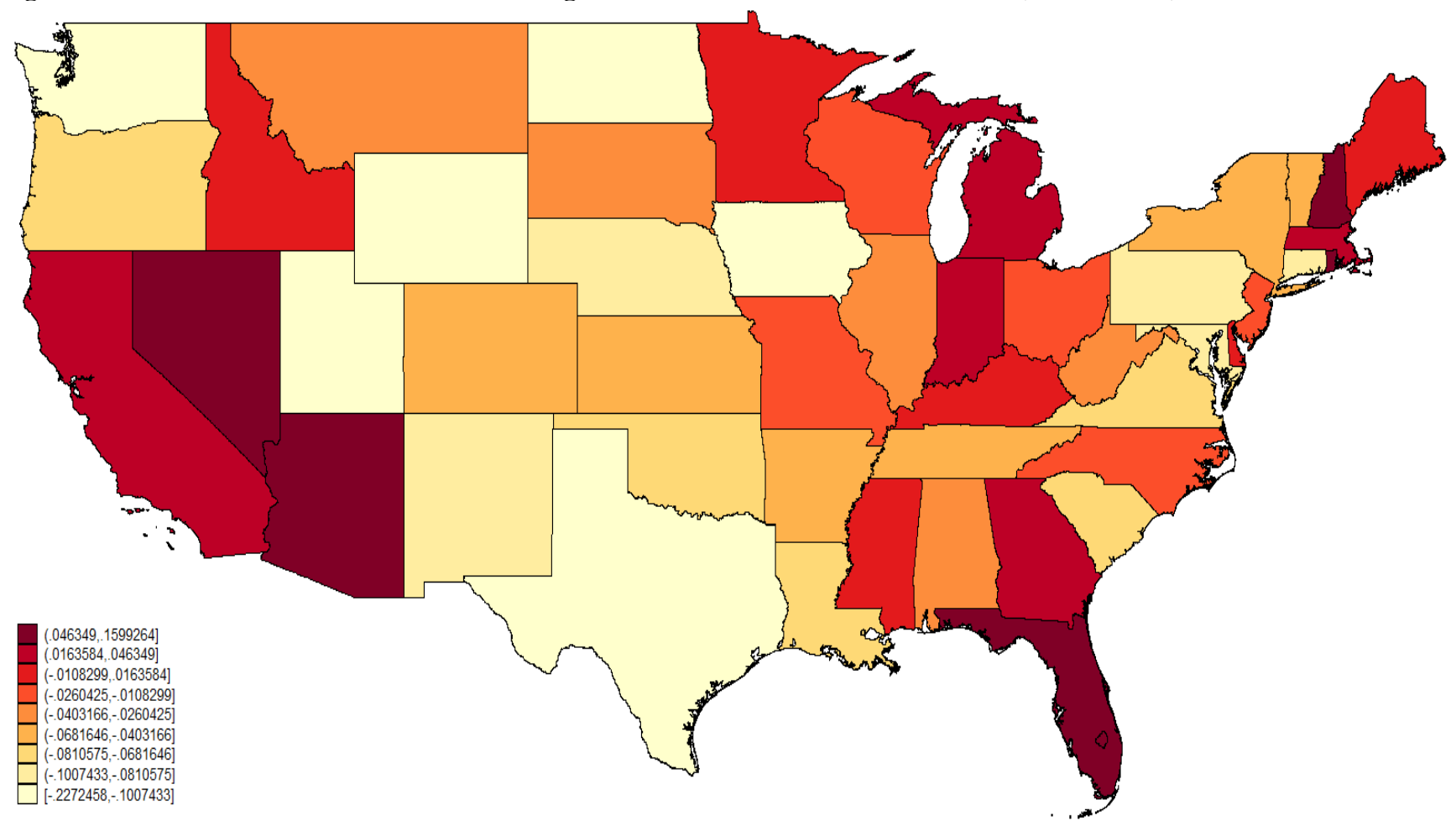

Note: School district revenues are aggregated at the state level. The darkest shades represent the highest percent decline in revenues while the lighter shades represent lower declines or even negative declines (i.e., revenue growth). 
Figure 8. Percent Decline in State Intergovernmental Transfers to School Districts (2007 to 2009)

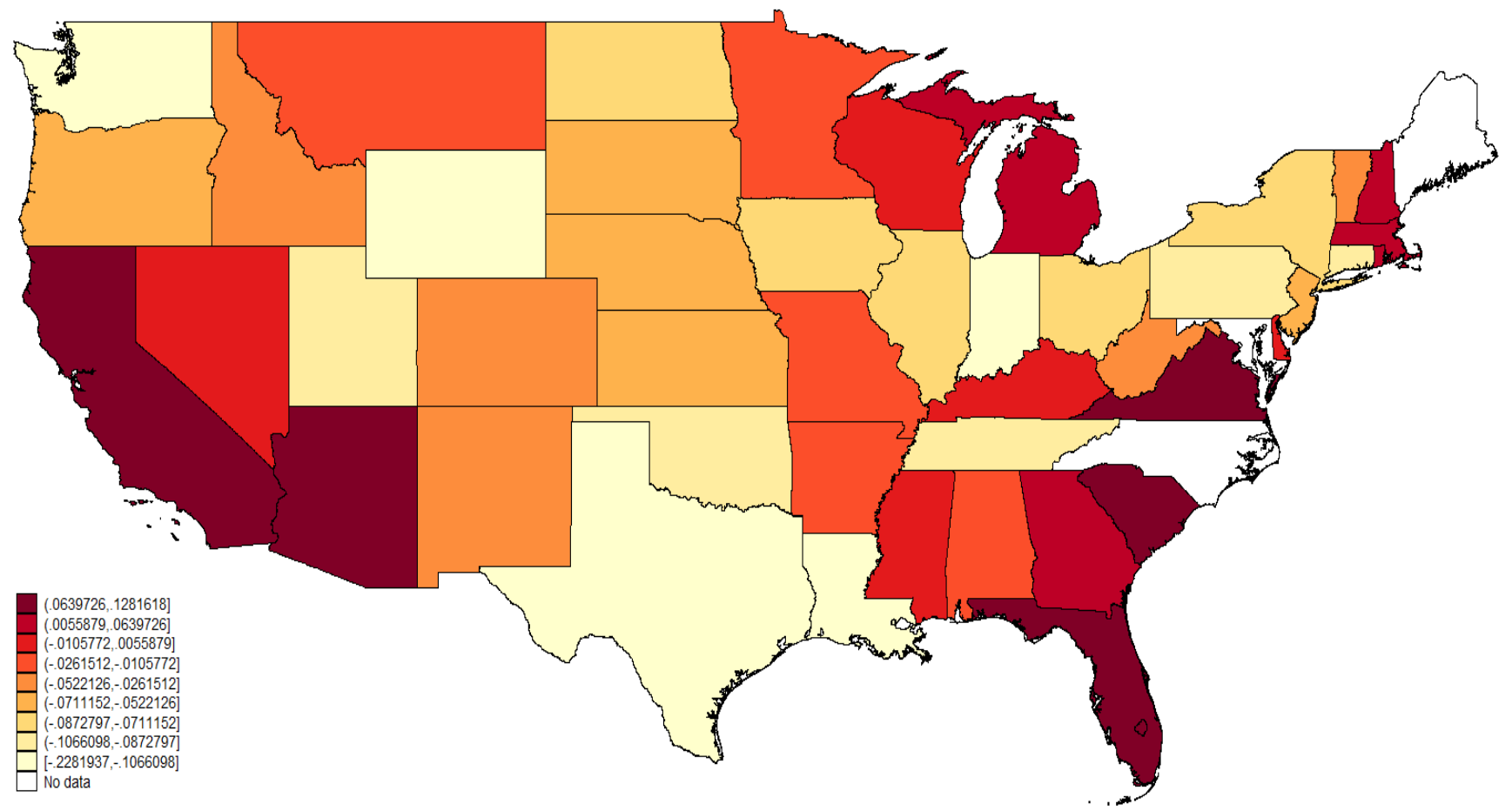

Note: The darkest shades represent the highest percent decline in transfers/expenditures while the lighter shades represent lower declines or even negative declines (i.e., growth). 


\section{Table 1. Descriptive Statistics}

\begin{tabular}{|c|c|c|c|c|}
\hline Variable & Mean & Std. Dev. & Minimum & Maximum \\
\hline Local Governments' Growth in Total Taxes (2007-2009) & 0.0620 & 0.0565 & -0.0843 & 0.1671 \\
\hline Local Governments' Growth in Property Taxes (2007-2009) & 0.0931 & 0.0602 & -0.0530 & 0.2703 \\
\hline Local Governments' Growth in Sales Taxes (2007-2009) & 0.0864 & 0.2614 & -0.2044 & 1.1602 \\
\hline Local Governments' Growth in Licenses (2007-2009) & -0.1423 & 0.1645 & -0.6136 & 0.1806 \\
\hline Local Governments' Growth in Revenues from State Government (2007-2009) & 0.0326 & 0.0762 & -0.1907 & 0.1984 \\
\hline School Districts' Growth in Total Revenues (2007-2009) & 0.0300 & 0.0622 & -0.1475 & 0.1859 \\
\hline School Districts' Growth in Revenues from State Government (2007-2009) & 0.0280 & 0.0986 & -0.2718 & 0.2321 \\
\hline School Districts' Growth in Revenues from Own Sources (2007-2009) & 0.0285 & 0.1506 & -0.7245 & 0.6218 \\
\hline School Districts' Growth in Revenues from Local Property Taxes (2007-2009) & 0.0745 & 0.0728 & -0.1003 & 0.3000 \\
\hline Ln(Per Capita Income $)(2005)$ & 10.4514 & 0.1476 & 10.1817 & 10.8521 \\
\hline Unemployment Rate (2000) & 4.8534 & 0.9161 & 3.0000 & 7.0417 \\
\hline House Price Growth (2000-2005) & 0.5865 & 0.3585 & 0.1449 & 1.4022 \\
\hline Percent Male (2000) & 0.4914 & 0.0082 & 0.4710 & 0.5170 \\
\hline Percent White (2000) & 0.7852 & 0.1453 & 0.2428 & 0.9695 \\
\hline Percent Hispanic (2000) & 0.0779 & 0.0882 & 0.0068 & 0.4208 \\
\hline Percent of Owner Occupied Homes (2000) & 0.6068 & 0.0497 & 0.4080 & 0.6839 \\
\hline Percent with Bachelor's Degree or More (2000) & 0.1584 & 0.0442 & 0.1012 & 0.3910 \\
\hline Percent Urban (2000) & 0.3101 & 0.1126 & 0.1623 & 1.0000 \\
\hline Percent of Families with Income $<25,000$ & 0.2947 & 0.0566 & 0.2062 & 0.4284 \\
\hline Percent of Families in Poverty (2000) & 0.0621 & 0.0247 & 0.0294 & 0.1670 \\
\hline Average Household Size $(\mathbf{2 0 0 0})$ & 2.5362 & 0.1301 & 2.1560 & 3.0441 \\
\hline Percent of Revenues from State Government (2006) & 49.7353 & 14.8580 & 0.0000 & 89.9000 \\
\hline New Foreclosures (Per Housing Unit, 2008-2009) & 0.0165 & 0.0178 & 0.0001 & 0.0929 \\
\hline
\end{tabular}


Table 2: New Foreclosures and Local Government Revenue Growth

\begin{tabular}{|c|c|c|c|c|c|c|}
\hline & \multirow[t]{2}{*}{ First Stage } & \multicolumn{5}{|c|}{ Second Stage } \\
\hline & & Total Taxes & $\begin{array}{c}\text { Property } \\
\text { Taxes }\end{array}$ & Sales Taxes & Licenses & $\begin{array}{c}\text { Revenues } \\
\text { from State } \\
\text { Government }\end{array}$ \\
\hline Ln(Per Capita Income) (2005) & $\begin{array}{r}-0.04798 \\
(0.0316)\end{array}$ & $\begin{array}{l}-0.32405 * * \\
(0.1476)\end{array}$ & $\begin{array}{c}-0.40071 * * \\
(0.1653)\end{array}$ & $\begin{array}{c}-1.57206 * * * \\
(0.6126)\end{array}$ & $\begin{array}{l}0.53899 \\
(0.3871)\end{array}$ & $\begin{array}{r}-0.17624 \\
(0.2433)\end{array}$ \\
\hline Unemployment Rate (2000) & $\begin{array}{r}-0.00021 \\
(0.0022)\end{array}$ & $\begin{array}{l}0.00404 \\
(0.0076)\end{array}$ & $\begin{array}{r}-0.00238 \\
(0.0091)\end{array}$ & $\begin{array}{l}0.01139 \\
(0.0374)\end{array}$ & $\begin{array}{r}-0.01573 \\
(0.0257)\end{array}$ & $\begin{array}{r}-0.01558 \\
(0.0160)\end{array}$ \\
\hline House Price Growth (2000-2005) & $\begin{array}{l}0.02337 * * \\
(0.0091)\end{array}$ & $\begin{array}{l}0.11697 * * \\
(0.0525)\end{array}$ & $\begin{array}{l}0.17925 * * \\
(0.0820)\end{array}$ & $\begin{array}{l}0.29335 \\
(0.2357)\end{array}$ & $\begin{array}{r}-0.02268 \\
(0.1301)\end{array}$ & $\begin{array}{l}0.01160 \\
(0.0815)\end{array}$ \\
\hline Percent Male (2000) & $\begin{array}{l}0.25685 \\
(0.3619)\end{array}$ & $\begin{array}{l}3.77454 * * * \\
(1.4053)\end{array}$ & $\begin{array}{l}3.24871 * \\
(1.9162)\end{array}$ & $\begin{array}{l}15.87423 * * * \\
(5.8791)\end{array}$ & $\begin{array}{l}4.00955 \\
(3.1753)\end{array}$ & $\begin{array}{l}7.58787 * * * \\
(2.8272)\end{array}$ \\
\hline Percent White (2000) & $\begin{array}{l}0.02755 \\
(0.0236)\end{array}$ & $\begin{array}{r}-0.01624 \\
(0.0850)\end{array}$ & $\begin{array}{l}0.07250 \\
(0.1293)\end{array}$ & $\begin{array}{c}-0.89518 * * \\
(0.4446)\end{array}$ & $\begin{array}{l}0.06549 \\
(0.2355)\end{array}$ & $\begin{array}{l}0.14619 \\
(0.2248)\end{array}$ \\
\hline Percent Hispanic (2000) & $\begin{array}{l}0.04396 \\
(0.0361)\end{array}$ & $\begin{array}{l}0.08102 \\
(0.0675)\end{array}$ & $\begin{array}{l}0.16246 \\
(0.1008)\end{array}$ & $\begin{array}{c}-0.43605 * * \\
(0.2055)\end{array}$ & $\begin{array}{c}-0.81157 * * \\
(0.3568)\end{array}$ & $\begin{array}{r}-0.18685 \\
(0.1971)\end{array}$ \\
\hline Percent of Owner Occupied Homes (2000) & $\begin{array}{l}0.03270 \\
(0.0482)\end{array}$ & $\begin{array}{l}0.32125 \\
(0.2048)\end{array}$ & $\begin{array}{l}0.63252 * * \\
(0.3021)\end{array}$ & $\begin{array}{r}-0.79097 \\
(1.0756)\end{array}$ & $\begin{array}{l}0.54059 \\
(0.5748)\end{array}$ & $\begin{array}{r}-0.07051 \\
(0.2880)\end{array}$ \\
\hline Percent with Bachelor's Degree or More (2000) & $\begin{array}{r}-0.24668 \\
(0.1550)\end{array}$ & $\begin{array}{l}0.22076 \\
(0.7216)\end{array}$ & $\begin{array}{l}0.01194 \\
(1.0680)\end{array}$ & $\begin{array}{l}0.29034 \\
(2.2635)\end{array}$ & $\begin{array}{r}-2.11209 \\
(1.8656)\end{array}$ & $\begin{array}{r}-0.35322 \\
(0.7595)\end{array}$ \\
\hline Percent Urban (2000) & $\begin{array}{l}0.08965 * * \\
(0.0406)\end{array}$ & $\begin{array}{r}-0.05104 \\
(0.2078)\end{array}$ & $\begin{array}{l}0.04510 \\
(0.2898)\end{array}$ & $\begin{array}{l}0.02191 \\
(0.7638)\end{array}$ & $\begin{array}{l}0.37699 \\
(0.5820)\end{array}$ & $\begin{array}{l}0.62323 \\
(0.5536)\end{array}$ \\
\hline Percent of Families with Income $<25,000$ (2000) & $\begin{array}{r}-0.21329 \\
(0.1440)\end{array}$ & $\begin{array}{r}-0.42921 \\
(0.7139)\end{array}$ & $\begin{array}{r}-1.01334 \\
(0.9256)\end{array}$ & $\begin{array}{r}-1.86480 \\
(2.7159)\end{array}$ & $\begin{array}{r}-1.25651 \\
(2.0115)\end{array}$ & $\begin{array}{r}-1.57794 \\
(1.5403)\end{array}$ \\
\hline Percent of Families in Poverty (2000) & $\begin{array}{l}0.16693 \\
(0.3207)\end{array}$ & $\begin{array}{l}0.20301 \\
(1.1542)\end{array}$ & $\begin{array}{l}2.16096 \\
(1.7127)\end{array}$ & $\begin{array}{r}-1.83723 \\
(5.4283)\end{array}$ & $\begin{array}{l}4.50953 \\
(3.0867)\end{array}$ & $\begin{array}{l}4.41904 \\
(4.0334)\end{array}$ \\
\hline Average Household Size (2000) & $\begin{array}{r}-0.01270 \\
(0.0329)\end{array}$ & $\begin{array}{r}-0.04312 \\
(0.1029)\end{array}$ & $\begin{array}{r}-0.09788 \\
(0.1414)\end{array}$ & $\begin{array}{r}-0.48617 \\
(0.3611)\end{array}$ & $\begin{array}{r}-0.18571 \\
(0.2095)\end{array}$ & $\begin{array}{r}-0.09481 \\
(0.1794)\end{array}$ \\
\hline Judicial Requirement & $\begin{array}{l}-\mathbf{0 . 0 0 8 8 9} * * \\
(0.0036)\end{array}$ & & & & & \\
\hline Constant & $\begin{array}{l}0.43363 \\
(0.4184)\end{array}$ & $\begin{array}{l}1.57683 \\
(1.7914)\end{array}$ & $\begin{array}{l}2.59484 \\
(1.9308)\end{array}$ & $\begin{array}{c}11.68702 * \\
(6.3366)\end{array}$ & $\begin{array}{r}-7.12020 \\
(4.5367)\end{array}$ & $\begin{array}{r}-1.43946 \\
(2.2189)\end{array}$ \\
\hline New Foreclosures & & $\begin{array}{l}-3.34974 * * \\
(1.6383)\end{array}$ & $\begin{array}{r}-3.65206 \\
(2.2613)\end{array}$ & $\begin{array}{r}-9.27594 \\
(6.0664)\end{array}$ & $\begin{array}{r}-4.43382 \\
(4.3869)\end{array}$ & $\begin{array}{l}-5.89165 * * \\
(2.5212)\end{array}$ \\
\hline $\begin{array}{l}\text { First Stage F-Statistic } \\
\text { Probaility }>\text { F }\end{array}$ & $\begin{array}{r}4.62 \\
0.0001\end{array}$ & & & & & \\
\hline $\mathrm{N}$ & & 51 & 51 & 35 & 51 & 50 \\
\hline $\mathrm{R}^{2}$ & & 0.4473 & 0.0252 & 0.6943 & 0.4753 & 0.3711 \\
\hline
\end{tabular}


Table 3: New Foreclosures and School District Revenue Growth

\begin{tabular}{|c|c|c|c|c|c|}
\hline & \multirow[t]{2}{*}{ First Stage } & \multicolumn{4}{|c|}{ Second Stage } \\
\hline & & Total Revenues & $\begin{array}{c}\text { Revenues From } \\
\text { State } \\
\text { Government }\end{array}$ & $\begin{array}{c}\text { Revenues from } \\
\text { Own Sources }\end{array}$ & $\begin{array}{c}\text { Revenues from } \\
\text { Local Property } \\
\text { Taxes }\end{array}$ \\
\hline Ln(Per Capita Income) (2005) & $\begin{array}{l}-0.08686 \text { ** } \\
(0.0414)\end{array}$ & $\begin{array}{l}0.02314 \\
(0.1720)\end{array}$ & $\begin{array}{l}0.08927 \\
(0.3406)\end{array}$ & $\begin{array}{r}-0.33703 \\
(0.4514)\end{array}$ & $\begin{array}{r}-0.26620 \\
(0.5008)\end{array}$ \\
\hline Unemployment Rate (2000) & $\begin{array}{r}-0.00221 \\
(0.0027)\end{array}$ & $\begin{array}{l}0.01618 * \\
(0.0087)\end{array}$ & $\begin{array}{l}0.01226 \\
(0.0172)\end{array}$ & $\begin{array}{r}-0.03359 \\
(0.0252)\end{array}$ & $\begin{array}{r}-0.00271 \\
(0.0157)\end{array}$ \\
\hline House Price Growth (2000-2005) & $\begin{array}{l}0.02164 * * \\
(0.0092)\end{array}$ & $\begin{array}{r}-0.00992 \\
(0.0579)\end{array}$ & $\begin{array}{l}0.00495 \\
(0.1140)\end{array}$ & $\begin{array}{r}-0.06353 \\
(0.1243)\end{array}$ & $\begin{array}{l}0.03452 \\
(0.0867)\end{array}$ \\
\hline Percent Male (2000) & $\begin{array}{l}0.61065 \\
(0.4083)\end{array}$ & $\begin{array}{l}3.10822 * \\
(1.8682)\end{array}$ & $\begin{array}{l}7.96951 \text { ** } \\
(3.8804)\end{array}$ & $\begin{array}{l}2.20624 \\
(3.8892)\end{array}$ & $\begin{array}{r}-3.66009 \\
(3.3769)\end{array}$ \\
\hline Percent White (2000) & $\begin{array}{l}0.04751 * \\
(0.0257)\end{array}$ & $\begin{array}{l}0.22554 * \\
(0.1313)\end{array}$ & $\begin{array}{l}0.31901 \\
(0.2929)\end{array}$ & $\begin{array}{r}-0.54424 \\
(0.3554)\end{array}$ & $\begin{array}{r}-0.07096 \\
(0.2348)\end{array}$ \\
\hline Percent Hispanic (2000) & $\begin{array}{r}-0.00669 \\
(0.0356)\end{array}$ & $\begin{array}{l}0.00106 \\
(0.1414)\end{array}$ & $\begin{array}{r}-0.06358 \\
(0.1955)\end{array}$ & $\begin{array}{r}-0.24633 \\
(0.3377)\end{array}$ & $\begin{array}{l}0.28334 \\
(0.2079)\end{array}$ \\
\hline Percent of Owner Occupied Homes (2000) & $\begin{array}{r}-0.00644 \\
(0.0543)\end{array}$ & $\begin{array}{l}0.11790 \\
(0.2555)\end{array}$ & $\begin{array}{l}0.29892 \\
(0.4432)\end{array}$ & $\begin{array}{l}0.07482 \\
(0.7491)\end{array}$ & $\begin{array}{r}-0.18509 \\
(0.3318)\end{array}$ \\
\hline Percent with Bachelor's Degree or More (2000) & $\begin{array}{r}-0.12681 \\
(0.1530)\end{array}$ & $\begin{array}{l}-0.80188 * \\
(0.4851)\end{array}$ & $\begin{array}{r}-0.66007 \\
(0.9749)\end{array}$ & $\begin{array}{r}-1.29259 \\
(1.3564)\end{array}$ & $\begin{array}{r}-0.29377 \\
(0.9913)\end{array}$ \\
\hline Percent Urban (2000) & $\begin{array}{l}0.16840 \text { *** } \\
(0.0593)\end{array}$ & $\begin{array}{l}0.22774 \\
(0.3635)\end{array}$ & $\begin{array}{l}0.12452 \\
(0.6479)\end{array}$ & $\begin{array}{l}1.00860 \\
(0.7247)\end{array}$ & $\begin{array}{r}-0.27867 \\
(0.4561)\end{array}$ \\
\hline Percent of Families with Income $<25,000$ & $\begin{array}{l}-0.39756 * * \\
(0.1752)\end{array}$ & $\begin{array}{r}-0.97590 \\
(0.8933)\end{array}$ & $\begin{array}{r}-1.62379 \\
(2.0443)\end{array}$ & $\begin{array}{r}-0.62410 \\
(1.7834)\end{array}$ & $\begin{array}{l}0.16005 \\
(1.4496)\end{array}$ \\
\hline Percent of Families in Poverty (2000) & $\begin{array}{l}0.82793 * \\
(0.4522)\end{array}$ & $\begin{array}{l}1.97282 \\
(2.3246)\end{array}$ & $\begin{array}{l}5.20400 \\
(5.1654)\end{array}$ & $\begin{array}{r}-0.51110 \\
(4.0130)\end{array}$ & $\begin{array}{r}-2.46825 \\
(2.1358)\end{array}$ \\
\hline Average Household Size (2000) & $\begin{array}{r}-0.04501 \\
(0.0322)\end{array}$ & $\begin{array}{r}-0.05942 \\
(0.1235)\end{array}$ & $\begin{array}{r}-0.10164 \\
(0.2816)\end{array}$ & $\begin{array}{r}-0.21860 \\
(0.2435)\end{array}$ & $\begin{array}{r}-0.04484 \\
(0.1927)\end{array}$ \\
\hline Percent of Revenues from State Government (2006) & $\begin{array}{r}-0.00022 \\
(0.0002)\end{array}$ & $\begin{array}{r}-0.00094 \\
(0.0007)\end{array}$ & $\begin{array}{l}-0.00213 * \\
(0.0011)\end{array}$ & $\begin{array}{l}0.00025 \\
(0.0022)\end{array}$ & $\begin{array}{l}0.00240 * * * \\
(0.0009)\end{array}$ \\
\hline Judicial Requirement & $\begin{array}{l}-0.00996 \text { *** } \\
(0.0035)\end{array}$ & & & & \\
\hline Constant & $\begin{array}{l}0.75529 \\
(0.4818)\end{array}$ & $\begin{array}{r}-1.60167 \\
(1.6292)\end{array}$ & $\begin{array}{c}-4.624375 * \\
2.718348\end{array}$ & $\begin{array}{l}3.69706 \\
(5.2264)\end{array}$ & $\begin{array}{l}4.99924 \\
(5.2112)\end{array}$ \\
\hline New Foreclosures & & $\begin{array}{r}-2.22920 \\
(1.5358)\end{array}$ & $\begin{array}{l}-5.779211 * \\
3.133128\end{array}$ & $\begin{array}{l}1.85710 \\
(3.7010)\end{array}$ & $\begin{array}{l}\mathbf{0 . 8 6 3 8 6} \\
(2.6654)\end{array}$ \\
\hline $\begin{array}{l}\text { First Stage F-Statistic } \\
\text { Probaility }>\text { F }\end{array}$ & $\begin{array}{r}4.26 \\
0.0002 \\
\end{array}$ & & & & \\
\hline $\mathrm{N}$ & & 51 & 50 & 51 & 42 \\
\hline $\mathrm{R}^{2}$ & & 0.4744 & 0.3393 & 0.2956 & 0.3420 \\
\hline
\end{tabular}


Table 4: State-Border Pair Results for New Foreclosures and Local Government Revenue Growth

\begin{tabular}{lcccccc}
\hline & New Foreclosures & Total Taxes & $\begin{array}{c}\text { Property } \\
\text { Taxes }\end{array}$ & Sales Taxes & $\begin{array}{c}\text { Licenses } \\
\text { Revenues } \\
\text { from State } \\
\text { Government }\end{array}$ \\
\cline { 3 - 7 } Judicial Requirement & $-0.00785 * *$ & & & & \\
New Foreclosures & $(0.0039)$ & & & & & \\
& & $-3.40573 *$ & -4.29738 & -5.49352 & 2.90986 & $-5.63913 * *$ \\
& & $(1.9173)$ & $(2.7115)$ & $(5.4595)$ & $(5.7842)$ & $(2.4868)$ \\
\hline
\end{tabular}

The F-Statistic for the first stage and its corresponding p-value are 4.11 and $0.045 . *, * * * *$ are coefficients statistically different from zero at the $10 \%$, $5 \%$, and $1 \%$ significance level, respectively.

Table 5: State-Border Pair Results for New Foreclosures and School District Revenue Growth

\begin{tabular}{lccccc}
\hline & New Foreclosures & $\begin{array}{c}\text { Total } \\
\text { Revenues }\end{array}$ & $\begin{array}{c}\text { Revenues } \\
\text { From State } \\
\text { Government }\end{array}$ & $\begin{array}{c}\text { Revenues } \\
\text { from Own } \\
\text { Sources }\end{array}$ & $\begin{array}{c}\text { Revenues from } \\
\text { Local Property } \\
\text { Taxes }\end{array}$ \\
\cline { 3 - 6 } Judicial Requirement & $-0.01227 * * *$ & & & & \\
& $(0.0039)$ & & & & \\
New Foreclosures & & & & & \\
& & $-1.77976 *$ & $-2.96770 *$ & 1.43379 & -3.22179 \\
& $(1.0719)$ & $(1.5401)$ & $(2.5736)$ & $(2.0326)$ \\
\hline
\end{tabular}

The F-Statistic for the first stage and its corresponding p-value are 10.04 and 0.002 . ****** are coefficients statistically different from zero at the $10 \%, 5 \%$, and $1 \%$ significance level, respectively. 
Table 6: New Foreclosures and State Government Revenue Growth

\begin{tabular}{|c|c|c|c|c|c|c|}
\hline & \multirow[t]{2}{*}{ First Stage } & \multicolumn{5}{|c|}{ Second Stage } \\
\hline & & Total Taxes & $\begin{array}{c}\text { Property } \\
\text { Taxes }\end{array}$ & $\begin{array}{l}\text { Sales } \\
\text { Taxes }\end{array}$ & Licenses & $\begin{array}{c}\text { Income } \\
\text { Taxes }\end{array}$ \\
\hline Ln(Per Capita Income) (2005) & $\begin{array}{c}-0.07671 * * \\
(0.0368)\end{array}$ & $\begin{array}{l}0.60907 * * \\
(0.2907)\end{array}$ & $\begin{array}{l}8.16139 \\
(5.0538)\end{array}$ & $\begin{array}{l}0.67256 * \\
(0.3691)\end{array}$ & $\begin{array}{l}0.83055 * \\
(0.4595)\end{array}$ & $\begin{array}{r}-0.45195 \\
(0.5394)\end{array}$ \\
\hline Unemployment Rate (2000) & $\begin{array}{r}-0.00318 \\
(0.0029)\end{array}$ & $\begin{array}{r}-0.00484 \\
(0.0184)\end{array}$ & $\begin{array}{l}0.13791 \\
(0.2793)\end{array}$ & $\begin{array}{r}-0.03101 \\
(0.0230)\end{array}$ & $\begin{array}{r}-0.01338 \\
(0.0323)\end{array}$ & $\begin{array}{l}0.00234 \\
(0.0243)\end{array}$ \\
\hline House Price Growth (2000-2005) & $\begin{array}{l}0.02096 * * \\
(0.0090)\end{array}$ & $\begin{array}{r}-0.04167 \\
(0.0736)\end{array}$ & $\begin{array}{l}-3.57053 * * \\
(1.4373)\end{array}$ & $\begin{array}{r}-0.10531 \\
(0.0902)\end{array}$ & $\begin{array}{r}-0.17741 \\
(0.1212)\end{array}$ & $\begin{array}{l}0.05447 \\
(0.0938)\end{array}$ \\
\hline Percent Male (2000) & $\begin{array}{l}0.54604 \\
(0.3697)\end{array}$ & $\begin{array}{l}7.53052 * * \\
(3.3729)\end{array}$ & $\begin{array}{r}-22.96822 \\
(22.3285)\end{array}$ & $\begin{array}{l}2.83978 \\
(4.4100)\end{array}$ & $\begin{array}{r}-5.36160 \\
(4.3907)\end{array}$ & $\begin{array}{l}1.08431 \\
(4.1266)\end{array}$ \\
\hline Percent White (2000) & $\begin{array}{l}0.06067 * * \\
(0.0285)\end{array}$ & $\begin{array}{l}0.15481 \\
(0.2181)\end{array}$ & $\begin{array}{l}2.35703 \\
(2.0596)\end{array}$ & $\begin{array}{r}-0.07594 \\
(0.2487)\end{array}$ & $\begin{array}{r}-0.28195 \\
(0.3540)\end{array}$ & $\begin{array}{l}0.31971 \\
(0.2902)\end{array}$ \\
\hline Percent Hispanic (2000) & $\begin{array}{r}-0.00192 \\
(0.0401)\end{array}$ & $\begin{array}{c}-0.32310 * * \\
(0.1260)\end{array}$ & $\begin{array}{r}-0.40277 \\
(1.9831)\end{array}$ & $\begin{array}{l}0.10504 \\
(0.1557)\end{array}$ & $\begin{array}{l}0.20187 \\
(0.2624)\end{array}$ & $\begin{array}{c}-0.63920 * \\
(0.3731)\end{array}$ \\
\hline Percent of Owner Occupied Homes (2000) & $\begin{array}{l}0.00250 \\
(0.0513)\end{array}$ & $\begin{array}{c}-0.52063 * \\
(0.2889)\end{array}$ & $\begin{array}{c}-13.52378 * * * \\
(5.1892)\end{array}$ & $\begin{array}{l}0.18977 \\
(0.3274)\end{array}$ & $\begin{array}{r}-0.26319 \\
(0.4470)\end{array}$ & $\begin{array}{r}-0.19623 \\
(0.4487)\end{array}$ \\
\hline Percent with Bachelor's Degree or More (2000) & $\begin{array}{r}-0.16121 \\
(0.1487)\end{array}$ & $\begin{array}{c}-1.65437 * * \\
(0.7237)\end{array}$ & $\begin{array}{l}20.98820 * \\
(10.7916)\end{array}$ & $\begin{array}{c}-1.75315 * \\
(1.0308)\end{array}$ & $\begin{array}{r}-1.57165 \\
(1.6943)\end{array}$ & $\begin{array}{l}0.96703 \\
(1.0401)\end{array}$ \\
\hline Percent Urban (2000) & $\begin{array}{l}0.16771 * * * \\
(0.0608)\end{array}$ & $\begin{array}{r}-0.01688 \\
(0.5496)\end{array}$ & $\begin{array}{r}-3.87850 \\
(6.9449)\end{array}$ & $\begin{array}{r}-0.19416 \\
(0.6213)\end{array}$ & $\begin{array}{r}-1.02918 \\
(0.8636)\end{array}$ & $\begin{array}{l}0.48458 \\
(0.7584)\end{array}$ \\
\hline Percent of Families with Income $<25,000$ & $\begin{array}{l}-0.40472 * * \\
(0.1768)\end{array}$ & $\begin{array}{l}0.34181 \\
(1.4513)\end{array}$ & $\begin{array}{r}3.23390 \\
(14.1080)\end{array}$ & $\begin{array}{l}0.46825 \\
(1.8807)\end{array}$ & $\begin{array}{l}1.88392 \\
(2.6828)\end{array}$ & $\begin{array}{r}-1.97103 \\
(2.1464)\end{array}$ \\
\hline Percent of Families in Poverty (2000) & $\begin{array}{l}0.85211 * \\
(0.4635)\end{array}$ & $\begin{array}{l}1.02391 \\
(3.4142)\end{array}$ & $\begin{array}{l}34.87806 \\
(24.0754)\end{array}$ & $\begin{array}{r}-0.79658 \\
(4.0565)\end{array}$ & $\begin{array}{r}-5.03138 \\
(5.7609)\end{array}$ & $\begin{array}{l}5.58978 \\
(4.7509)\end{array}$ \\
\hline Average Household Size (2000) & $\begin{array}{r}-0.03653 \\
(0.0339)\end{array}$ & $\begin{array}{r}-0.00555 \\
(0.1862)\end{array}$ & $\begin{array}{r}-1.13873 \\
(1.7561)\end{array}$ & $\begin{array}{r}-0.10417 \\
(0.2140)\end{array}$ & $\begin{array}{l}0.13345 \\
(0.3100)\end{array}$ & $\begin{array}{r}-0.37726 \\
(0.2868)\end{array}$ \\
\hline Judicial Requirement & $\begin{array}{l}-\mathbf{0 . 0 0 8 7 1} * * \\
(0.0037)\end{array}$ & & & & & \\
\hline Constant & $\begin{array}{l}0.64274 \\
(0.4405)\end{array}$ & $\begin{array}{l}-9.70281 * * * \\
(2.7280)\end{array}$ & $\begin{array}{r}-68.80984 \\
(51.9374)\end{array}$ & $\begin{array}{l}-7.79260 * \\
(4.1974)\end{array}$ & $\begin{array}{r}-5.65382 \\
(4.6422)\end{array}$ & $\begin{array}{l}4.85977 \\
(5.7932)\end{array}$ \\
\hline New Foreclosures & & $\begin{array}{r}-3.61032 \\
(2.8264)\end{array}$ & $\begin{array}{l}31.01046 \\
(25.5127)\end{array}$ & $\begin{array}{r}-2.73402 \\
(3.1940)\end{array}$ & $\begin{array}{l}4.73229 \\
(4.5088)\end{array}$ & $\begin{array}{r}-3.96766 \\
(3.4068)\end{array}$ \\
\hline $\begin{array}{l}\text { First Stage F-Statistic } \\
\text { Probaility }>\text { F }\end{array}$ & $\begin{array}{r}4.89 \\
0.00010 \\
\end{array}$ & & & & & \\
\hline $\mathrm{N}$ & & 50 & 36 & 50 & 50 & 46 \\
\hline $\mathrm{R}^{2}$ & & 0.6957 & 0.5524 & 0.1042 & 0.1136 & 0.3700 \\
\hline
\end{tabular}


Table 7: State-Border Pair Results for New Foreclosures and Changes to State Government Revenue Growth

\begin{tabular}{|c|c|c|c|c|c|c|}
\hline & New Foreclosures & Total Taxes & $\begin{array}{c}\text { Property } \\
\text { Taxes }\end{array}$ & Sales Taxes & Licenses & $\begin{array}{c}\text { Income } \\
\text { Taxes }\end{array}$ \\
\hline Judicial Requirement & $\begin{array}{l}-0.01060 * * * \\
(0.0040)\end{array}$ & & & & & \\
\hline New Foreclosures & & $\begin{array}{r}-0.21664 \\
(2.2753)\end{array}$ & $\begin{array}{r}8.56648 \\
(79.6149)\end{array}$ & $\begin{array}{r}-1.17810 \\
(2.4591)\end{array}$ & $\begin{array}{r}3.980393 \\
(3.4437)\end{array}$ & $\begin{array}{r}-0.91757 \\
(2.3901)\end{array}$ \\
\hline
\end{tabular}

The F-Statistic for the first stage and its corresponding p-value are 7.18 and $0.009 . * * *, * * *$ are coefficients statistically different from zero at the $10 \%, 5 \%$, and $1 \%$ significance level, respectively. 